The Quarterly Journal of Austrian Economics

Volume 24 | NO. 1 | 3-40 | SpRing 2021

WWW.QJAE.ORG

\title{
ReAsons For the Demise of INTEREST: SAVINGS GLUT AND Secular Stagnation or Central BANK POLICY?
}

\author{
Thomas Mayer and Gunther SchnabL*
}

\author{
JEL Classification: E12, E14, E32, E43
}

Aвstract: This article compares the Keynesian, neoclassical and Austrian explanations for low interest rates and sluggish growth. From a Keynesian and neoclassical perspective, low interest rates are attributed to aging societies, which save more for the future (global savings glut). Low growth is linked to slowing population growth and a declining marginal efficiency of investment as well as to declining fixed capital investment due to digitalization (secular stagnation). In contrast, from the perspective of Austrian business cycle theory, interest rates were decreased step by step by central banks to stimulate growth. This paralyzed investment and lowered growth in the long term. This study shows that the ability of banks to extend credit ex nihilo and the requirement of time to produce capital goods invalidates the permanent IS identity assumed in the Keynesian theory. Furthermore, it is found that there is no empirical evidence for the hypotheses of a global savings glut and secular stagnation. Instead, low growth can be explained by the emergence of quasi "soft budget constraints" as a result of low interest rates, which reduce the incentive for banks and enterprises to strive for efficiency.

\footnotetext{
* Thomas Mayer (Thomas.mayer@fvsag.com) is the founding director of the Flossbach von Storch Research Institute, Cologne, Germany. Gunther Schnabl (schabl@wifa. uni-leipzig.de) is a professor of international economics and economic policy in the department of economics at Leipzig University, Germany.
} 


\section{INTRODUCTION}

Since the 1980s, slower economic growth in the industrial Scountries has been accompanied by lower interest rates, with real interest rates turning negative more recently (figure 1). The fight against the economic consequences of the severe corona crisis has triggered an even stronger monetary expansion, with even more government bond yields falling into negative territory. At the same time, investment, productivity growth, and economic growth have continued to slow. Although to some observers the pivotal role of central banks in ever-lower levels of interest is evident, representatives of central banks have stressed structural factors as the reasons for low interest rates (Lane 2019, Schnabel 2020).

Figure 1. Nominal and Real Short-Term Interest Rates in the US, Japan, and Germany

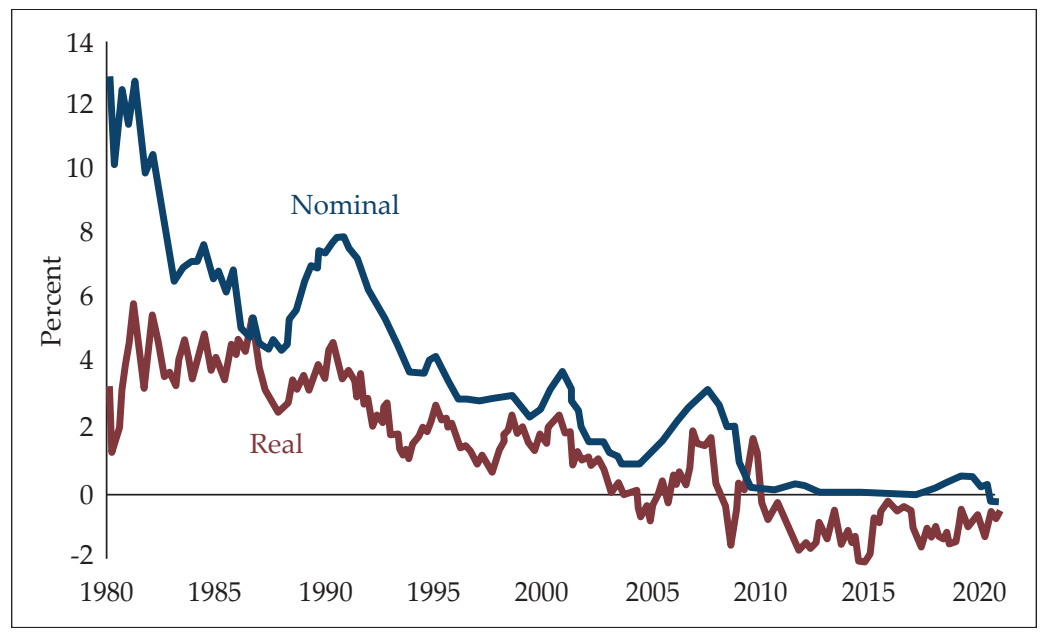

Source: IMF. Arithmetic mean. Real interest rates calculated based on official consumer price inflation statistics with hedonic price measurement.

Different schools of thought have provided different theoretical and empirical explanations. Based on Keynes (1936) and Hansen (1939), Bernanke (2005) and Summers (2014) have attributed secularly declining real interest rates to a global savings glut driven by aging societies, a declining demand for fixed capital investment, and a declining marginal efficiency of fixed capital investment (Gordon 2012). Łukasz and Summers (2019) argue that "the neutral 
real rate for the industrial world has trended downward for the last generation and this is best understood in terms of changes in private sector saving and investment propensities." According to their view, central banks are simply adjusting to the exogenous forces of secular stagnation when they set the interest rate at or below zero.

In contrast, from the point of view of Austrian economic theory in the tradition of Mises (1912) and Hayek (1931), human beings strive to achieve their goals earlier rather than later and thus have a "positive time preference." This makes negative interest rates under free market conditions impossible (Mises [1949] 1998). This view is in line with the finding of Homer and Sylla (2005) that through most of economic history real interest rates were positive. In this spirit, based on the monetary overinvestment theories of Mises (1912) and Hayek (1931) and in line with Borio and White (2004) and White (2006), Schnabl (2019) has argued that the gradual decline of interest rates in the industrialized countries has been due to asymmetric monetary policies: strong interest rate cuts during crises were not followed by respective increases during the postcrisis recovery.

The question of whether the gradual decline of real and nominal interest rates in the industrialized countries (and the rest of the world) is due to structural change, as suggested inter alia by Summers (2014) or due to policy decisions made by central banks is crucial for the economic policy agenda. The Keynesian interpretation can be used to justify further interest rate cuts, even below zero, ${ }^{1}$ as well as fiscal expansion. In contrast, from the Austrian point of view only renouncing policies that have led to low and even negative interest rates can reanimate economic activity. This article compares the two approaches and derives policy implications.

\section{THE KEYNESIAN AND NEOCLASSICAL INTERPRETATION OF LOW INTEREST RATES AND GROWTH}

The close relationship between declining nominal and real interest rates and declining (productivity) growth is in the Keynesian and

\footnotetext{
${ }^{1}$ Agarwal and Kimball (2019) of the International Monetary Fund (IMF) have compiled a guide for central banks on how to enable deep negative interest rates in order to fight recessions.
} 
neoclassical view due to exogenous factors. Structural change leads to changes in supply and demand conditions in the capital markets, with the result that the real interest rate declines. In the spirit of Hansen (1939), Bernanke (2005) attributes a savings glut to the aging of societies. As people approach retirement age they are seen to save more for old age. When the cohort of aging people is large, in the Keynesian and neoclassical approach the aggregate supply of loanable funds and equity capital rises. At the same time, profitable investment opportunities are seen to decline, reducing the demand for loanable funds and equity capital (Summers 2014).

\section{Savings Glut, Secular Stagnation, and the Keynesian Natural Interest Rate}

Following the sharp interest rate cuts of the US Federal Reserve in response to the burst of the dot-com bubble at the beginning of the new millennium, Bernanke (2005) attributed an increase in the US current account deficit (i.e., growing net capital inflows to the US) and the decline of world interest rates to factors outside the US: "A global saving glut ... helps to explain both the increase in the US current account deficit and the relatively low level of long-term real interest rates in the world today." Bernanke (2005) argued that aging populations in a number of industrial countries and several emerging market economies, notably China, had transformed these countries from net borrowing to being net lenders on international capital markets, with the result of increased net capital flows to the US.

According to Bernanke (2005), East Asian countries prevented their exchange rates from appreciating and accumulated foreign reserves to boost the competitiveness of their exports and create war chests against balance of payments crises. ${ }^{2}$ Bernanke (2005) also observed higher US dollar earnings for oil- and raw materials-exporting countries due to rising oil prices, which were to a large extent recycled into US dollar investments. Before the subprime crisis, capital flows to the US were attracted by fast productivity growth, strong property rights, and a robust regulatory environment.

\footnotetext{
${ }^{2}$ In 1997-98, the Asian crisis, which had been caused by large net capital inflows, overinvestment, and current account deficits, put an abrupt end to the economic miracle in a number of Southeast Asian countries (Corsetti et al. 1999).
} 
After the outbreak of the subprime crisis, which culminated in the global financial crisis of 2007-08 and prompted the Federal Reserve (and other large central banks) to cut interest rates toward zero, Summers (2014) developed a comprehensive explanation for the global decline of nominal and real interest rates from a capital market perspective. On the supply side of the capital market, Summers (2014) linked low birth rates in industrialized countries to growing savings in the tradition of Hansen $(1939)^{3}$ and Bernanke (2005), who had argued that people in aging societies would save more for retirement. ${ }^{4}$ Summers associated growing income inequality with a declining marginal propensity to consume (an increasing propensity to save) in a large part of the population. ${ }^{5}$ Following Bernanke (2005), he identified accumulation of reserves in emerging market economies as a reason for the increased demand for safe assets available in the US. ${ }^{6}$

On the demand side of global capital markets, Summers (2014) linked a lower demand for fixed capital investment to changes in technology. He assumed that companies in the information and communication technology sector would have a lower demand for fixed capital. Like Bernanke (2005) and Gordon (2012), Summers (2014) argued that the potential of innovations to increase productivity had

\footnotetext{
${ }^{3}$ In the 1930s, Hansen (1939) had argued that low growth was caused by slowing population growth and limited scope for technological innovation. He had dubbed this phenomenon "secular stagnation."
}

${ }^{4}$ Keynes (1936) distinguishes eight savings motives from an individual perspective: preference for private profit (i.e., interest), intertemporal substitution motive, life-cycle motive due to decreasing income after retirement, precautionary motive, independence motive, enterprise motive, bequest motive, and avarice motive. The theory of a savings glut in an aging society randomly picks out the life-cycle motive and applies it to the entire society. Weizsäcker (2014) transferred Summers's (2014) concept to Germany and demanded an expansionary fiscal policy to lift interest rates. Meanwhile, the pressure on German fiscal policy to become more expansionary to increase the inflation rate (and thereby to allow the European Central Bank [ECB] to lift the interest rate) is growing.

${ }^{5}$ Keynes (1936) argued that the growth of income over time had increased the savings rate of the society, leading to a structural rise of savings over investment.

${ }^{6}$ As the Fed strongly cut interest rates in response to the burst of the dot-com bubble after the year 2000, capital flows to East Asia accelerated. With the East Asian countries stabilizing their exchange rates against the dollar, the accumulation of dollar reserves and thereby the purchases of US government bonds strongly increased (see McKinnon and Schnabl 2012). 
structurally declined. The resulting drop in the demand for capital goods was supposed to have been accompanied by lower prices for capital goods, leading to a further decline in investment spending in nominal terms. In Summers's (2014) view, rising household savings drag down expected aggregate demand, including corporate investment. Thus, corporate savings rise as well. ${ }^{7}$ When savings and investments are assumed to behave in line with these "stylized facts," the savings curve in the neoclassical capital market model shifts to the right and the investment curve to the left. The equilibrium (or natural/neutral) interest rate falls, possibly even below zero.

In the neoclassical theory it is assumed that the real interest rate is determined by the marginal productivity of capital on the demand side of the capital market and by the time preference of savers on the supply side. Thus, the market equilibrium interest rate is determined by the marginal return on capital (which drives the demand for capital) and the marginal utility of exchanging present goods against future goods (which determines the supply of capital). The equilibrium rate matching savings to investment has been called the neutral or natural rate.

The natural or neutral rate of interest is a theoretical concept and cannot be observed directly. ${ }^{8}$ A model is needed. Economists of a neoclassical persuasion have tried to derive it from the marginal product of capital of empirically estimated production functions. Those with a Keynesian preference have used Wicksell's (1898) notion of a given interest rate prevailing in economic equilibrium to define the natural rate as the interest rate which keeps price inflation stable and output growth at its potential (see Woodford 2003). ${ }^{9}$ Thus, Laubach and Williams (2015) as well as Rachel and

\footnotetext{
${ }^{7}$ Which can also take the form of hoarding cash.

${ }^{8}$ Mises (1944) argued that it is difficult to know the natural interest rate. In free markets, given sound money, long-term rates reflect on average the natural rate, which is determined by time preference (see below).

${ }^{9}$ Wicksell's (1898) natural rate ensures price stability (zero inflation). In contrast, the notion of the natural rate by Laubach and Williams (2015) as well as Rachel and Summers (2015) ensures a stable rate of price inflation (for example, 2 percent). The definition of Wicksell (1898) would imply in the modern world that the target for the inflation rate in the steady state is 0 percent. Also note that whereas Woodford (2003) assumes that the natural interest rate closes the output gap, this requirement is not found in Wicksell (1898).
} 
Summers (2019) define the natural or neutral interest rate as the real short-term interest rate consistent with the economy operating at its full potential, without upward or downward pressure on consumer price inflation. Gourinchas and Rey (2019) see a structural decline of the ratio of consumption to wealth as an indication of a decline of the natural interest rate. Following this line of thought would lead to the conclusion that rising asset prices drive down the natural interest rate.

Laubach and Williams (2015) as well as Rachel and Summers (2019) estimate the output gap via the Keynesian IS curve ${ }^{10}$ and inflation with the Phillips curve, which links price changes to the level of unemployment. As they find a negative output gap and declining (measured $)^{11}$ consumer price inflation, the natural or neutral interest rate estimated with their model declines from the 1980s. The decline has accelerated since the 2007-08 global financial crisis, with the natural interest rate turning negative recently. These findings are confirmed by the estimates of Jordá and Taylor (2019), who argue that half of the decline trend is due to structural factors, such as lower productivity growth and an aging population, and the rest to central bank policy.

To derive policy implications, Laubach and Williams (2015) apply the estimated natural interest rate to the Taylor (1993) rule. The original Taylor rule assumes a real interest rate of 2 percent, which was constant and close to the long-term US growth rate of 2.2 percent observed at the time. With an assumed inflation target of 2 percent, ${ }^{12}$ this implied at the time a long-term equilibrium or

${ }^{10}$ The IS curve represents all equilibrium combinations of the real interest rate, $r$, and the real income, $Y$, at which the goods market is ceteris paribus in equilibrium.

${ }^{11}$ Meanwhile, a discussion has emerged about whether officially measured inflation rates are understated or overstated. A core point in this discussion is how changes in quality of goods should be incorporated in inflation measurement (hedonic price measurement). Whereas one side argues that quality improvements are not sufficiently incorporated in hedonic price measurement (Feldstein 2017), others see declining quality being overlooked (Komlos 2018; Kitov 2012; Linz and Eckert 2002). Furthermore, the question arises, if asset price inflation (for instance for owner-occupied housing) should be included in inflation measurement, as monetary policy is increasingly transmitted to financial markets rather than goods markets (Schnabl 2015a).

${ }^{12}$ Note that different central banks use different measures of inflation for monetary policymaking.

Market participants claim that the Fed is targeting core PCE, as it aims to stabilize inflation "over the long run." The European Central Bank aims to keep the percent 
nominal natural interest rate of 4 percent, consistent with inflation and output at target levels. ${ }^{13}$ Inserting their estimates of a declining natural interest rate into the Taylor rule, Laubach and Williams (2015) arrive at the policy recommendation to gradually decrease the key policy interest rate toward or even below zero. If the natural interest rate falls, the policymaker has to cut the nominal interest rate to achieve the inflation target.

\section{The Keynesian-Neoclassical Framework}

In the seminal Keynesian macroeconomic framework, consumption is determined by real income $(Y)$, with the propensity to consume declining over time (as in Keynes 1936). Bernanke (2005) and Summers (2014) argue that the propensity to consume (propensity to save) declines (increases) when the population is aging and the working-age population is shrinking:

$$
\text { (equation 1) } C=k(D) Y
$$

where $C$ denotes real consumption, $k$ the marginal propensity to consume, $D$ the aging (shrinking) of the (working-age) population, and $Y$ the real gross domestic product (GDP), with $D>0$ and $\frac{d k}{d D}<0 .{ }^{14}$

change rate of the Harmonized Consumer Prices Index at "close to but less than $2 \% "$ in the medium term. It is unclear whether the ECB is targeting headline or core inflation. An increasing number of commentators think that the ECB targets core inflation rather than headline inflation as in the past. The reason is that in cases when headline inflation was close to 2 percent while core inflation was substantially below 2 percent, ECB representatives claimed to have missed the target. More generally, the ECB (2016) claims that "many central banks, including the ECB, monitor a wide range of underlying inflation measures, which abstract from short-term volatility, to gauge inflationary trends. In addition to HICP inflation excluding energy and food, the ECB monitors various exclusion-based measures and model-based measures of inflation, as well as developments in long-term inflation expectations." The Bank of Japan (2013) "sets the 'price stability target' at 2 percent in terms of the year-on-year rate of change in the consumer price index (CPI) - a main price index."

${ }^{13}$ The Taylor rule is $i=r^{*}+\pi^{*}+0.5\left(\pi-\pi^{*}\right)+0.5\left(y-y^{*}\right)$, with i being the nominal (central bank target) interest rate, $r^{*}$ being the real interest rate (assumed to be constant in the long term), $\pi$ being the inflation rate, and $y$ being real output. $\pi^{*}$ marks the inflation target and $y^{*}$ the trend output.

${ }^{14}$ The view that savings increase when a population ages is based on considerations of plausibility instead of empirical observations. It is argued that working age people save for retirement as they grow older. At the same time, however, retirees 
Real investment, $I$, is a function of the real interest rate, $i$ :

(equation 2) $I=I(i)$

Investment increases when the interest rate falls $\left(\frac{d I}{d i}<0\right)$.

The price level, $P$, is a function of the economy-wide capacity utilization (output gap), measured by the ratio between actual real $\operatorname{GDP}(Y)$ and potential real GDP $\left(Y^{p o t}\right)$.

(equation 3) $P=P\left(\frac{Y}{Y^{p o t}}\right)$

Prices rise when real output grows above potential $\frac{d P}{d\left(\frac{Y}{Y p o t}\right)}>0$.

Real GDP in a closed economy is the sum of consumption and investment:

(equation 4) $Y=C+I$

Inserting (1) and (2) in (4) and solving for $Y$ yields:

(equation 5) $Y=\frac{I(i)}{(1-k(D))}$

Substituting (5) into (3) gives:

(equation 6) $P=P\left(\frac{\frac{I(i)}{(1-k(D))}}{Y^{\text {pot }}}\right)$

In this framework, if a society is aging, the propensity to consume, $k$, decreases, and the price level and output fall. To compensate for this effect, a central bank pursuing an inflation target needs to decrease the real interest rate to increase investment, output, and thereby the price level again, as explained by Laubach and Williams (2015) as well as by Rachel and Summers (2019). Interest rate cuts are necessary to maintain the inflation target and an equilibrium in the goods market.

The IS model abstracts from the supply side, as potential output is assumed to be given exogenously. It can be augmented, however, by adding a neoclassical element in the form of a production function where potential output is dependent on the capital stock, $K$ :

(equation 8) $Y^{\text {pot }}=Y^{\text {pot }}(K)$

may dissave. Whether saving for retirement is greater or smaller than dissaving in retirement is an empirical issue which Bernanke (2005) and Summers (2014) regard as resolved by their observation that populations are aging and interest rates are declining. 
with the change in the capital stock being equivalent to investment $(\Delta K=I) .{ }^{15}$ Assuming profit maximization, the marginal product of capital equals its real return, $r$ :

$$
\text { (equation 9) } r=\frac{\Delta Y^{p o t}}{\Delta K}=\frac{\Delta Y^{p o t}}{I}
$$

An investment project would usually only be financed when the real return is expected to be larger than the real interest rate on credit $(i)$ plus the risk premium $(r p)$. Hence,

$$
\text { (equation 10) } i=\frac{\Delta Y^{p o t}}{I}+r p
$$

where $r p$ is assumed to be constant for the sake of simplicity.

The upshot is that the propensity to consume $(k)$ falls when the population ages, and savings increase (as $S=Y-C$ ). The resulting decline in demand and output prompts the central bank to reduce $i$. At the same time, as argued by Summers (2014) and Gordon (2012), investment and productivity growth decline, which lowers $r{ }^{16}$

\section{THE AUSTRIAN OVERINVESTMENT FRAMEWORK AND THE ROLE OF THE FINANCIAL SECTOR}

The overinvestment theory of Mises (1912) and Hayek (1931) says that a credit interest rate manipulated by the central bank below the natural interest rate at first induces an economic upswing, which is fueled by credit creation of the banking sector. ${ }^{17}$ When interest rates are lifted again by the central bank to contain inflation, the upswing turns into a downswing. When interest rates then are strongly cut in response to the downswing, distorted economic structures created during the upswing are conserved, which leads to persistently low growth.

\footnotetext{
${ }^{15}$ For parsimony we abstract from the depreciation of the capital stock.

${ }^{16}$ Note, however, that lower interest rates as a result of a savings glut (Summers 2014) conflict with the explanation of low interest rates as a result of slowing productivity growth (Gordon 2012). Summers (2014) assumes that the decline of output is due to increasing savings and declining consumption. This implies a decline of output below potential output from the demand side and therefore deflationary pressure. Gordon (2012) assumes a decline of potential output below output. This implies growing inflationary pressure from the supply side.

${ }^{17}$ For details see Schnabl (2019a).
} 


\section{The Austrian Overinvestment Framework}

According to Böhm-Bawerk (1884) and Mises (1940), the interest rate is a measure for time preference, with finitely living people assigning greater value to goods and services today than goods and services available at a future point in time. ${ }^{18}$ The borrowing of funds to produce capital goods requires the payment of interest as a compensation for the present consumption foregone on the part of the lender (agio). According to Böhm-Bawerk's (1884) concept of roundaboutness, this positive interest rate payment is possible if the time-consuming move to a more capital-intensive production process allows higher production in the future. If a roundabout method would not result in a more productive production process, people will not engage in time-consuming roundabouts of producing the capital goods required for an increase of consumption in the future. ${ }^{19}$

Before consumer goods can be produced, capital goods have to be produced. Whereas a high interest rate is an impediment for many investment projects with a comparatively low expected return, a low interest rate stimulates investment, as the costs of roundabouts decline. A lower interest rate signals higher present savings and as a result higher consumption in the future. This provides an incentive to increase capacity for the production of consumption goods. When some enterprises start to invest in response to a lower interest rate, they need inputs from other enterprises, which extend their production capacities as well.

A cumulative upswing sets in which is financed by credit creation of banks. ${ }^{20}$ This allows real investment (I) to temporarily exceed

\footnotetext{
${ }^{18}$ Therefore, in the view of Austrian economists, the interest rate always has to be positive, because it requires time to achieve a certain objective and time is scarce for mortal men.

${ }^{19}$ But they could hoard products for future consumption if needed.

${ }^{20}$ Ohlin (1937) argued in his loanable funds theory that nominal investment can be financed by nominal household savings $(S)$ and credit creation of banks $(\Delta C): I^{n}=$ $S^{n}+\Delta C$. To grant a credit to an enterprise or a household, the bank does not necessarily need to collect deposits from savers. By providing a loan, the bank enlarges its claims on the private sector on the asset side of the balance sheet. When the credit is transferred to the debtor's bank account, the deposits of the bank increase on the liability side of the balance sheet. This implies that private banks can
} 
real savings $(S)$. Banks create additional credit to keep interest rates aligned with the central bank interest rate. In the first phase of the upswing, when less than the full labor force is in use, wages do not increase. The profits of banks and enterprises grow, which is reflected in rising stock prices. ${ }^{21}$ When unemployment has declined to a very low level, the negotiating power of labor unions strengthens and wages rise. Enterprises have to lift prices to cover their costs, which pushes up inflation. When rising inflation forces the central bank to raise interest rates, the benchmark for the profitability of past and future investment projects is raised.

Owing to higher financing costs, incomplete investment projects need to be abandoned, and new investment projects become unprofitable. A cumulative downswing evolves. During the downswingaccording to the overinvestment theory-the central bank keeps the credit rate, via the central bank interest rate, above the natural interest rate, which falls as investment declines. As interest rate is kept above the natural interest rate, the downturn is aggravated. As unemployment grows, wages and prices fall. The dismantling of investment projects with low profitability and falling wages and prices are seen as prerequisites for the economic recovery. The downswing entails a cleansing effect (Schumpeter 1912), as resources can be shifted to higher return investment projects.

\section{Transmission via the Financial Sector}

In the Keynesian model the central bank steers the money market interest rate via the LM-curve by expanding the money supply. ${ }^{22}$ There are neither banks nor capital markets involved. In contrast,

increase the money supply $(\Delta M)$ by providing credit $(\Delta C)$. With the interest rate being determined by credit supply and demand, an exogenous extension of credit reduces the equilibrium interest rate.

${ }^{21}$ Hayek (1931) also acknowledges that during an upswing stock and real estate prices can become delinked from fundamentals as speculation sets in.

${ }^{22}$ The LM-curve represents all combinations of the real interest rate (i) and real output $(Y)$ at which the money market is in equilibrium. An equilibrium in the money market implies that money supply $(M)$ equals money demand $(L)$, which is equivalent to liquidity preference. According to Keynes's (1936) concept of liquidity preference, the interest is a monetary phenomenon, determined by supply and demand for money. 
in the Austrian model the banking sector transmits the interest rate policy of the central bank to credit rates through credit extension of banks. Investment can increase the fixed capital stock (nonfinancial investment, e.g., machinery for producing consumer or investment goods) or financial assets.

To model the role of banks in financing investment, the relationship between nominal savings and nominal investment can be represented as

(equation 11) $P^{n f} I^{n f}+P^{f} I^{f}=S^{n}+\Delta C$

The variable $P^{n f}$ denotes the price of real nonfinancial investment goods ( $\left(I^{n f}\right.$, fixed capital investment) and $P^{f}$ the price for real financial investments $\left(I^{f}\right)$ such as equities. $S^{n}$ is equivalent to (nominal) savings out of existing money, $\Delta C$ is the credit (and money) creation of banks. ${ }^{23}$ We assume that $I^{n f}, I^{f}$, and $\Delta C$ are all negative functions of the interest rate (i). If the interest rate falls, nonfinancial and financial investments grow and additional credit is created domestically. Savings are assumed to increase (fall), when the credit interest $i$ increases (falls).

The prices of nonfinancial investments and financial investments are assumed to depend positively on investment activity. If more is invested, the prices of the real and financial investment goods rise:

(equation 12) $P^{n f}=P^{n f}\left(I^{n f}\right)$ with $d P^{n f} / d I^{n f}$

(equation 13) $P^{f}=P^{f}\left(I^{f}\right)$ with $d P^{f} / d I^{f}>0$

If the credit interest rate $(i)$ declines, savings decrease. Non-financial investment and financial investment increase, with the additional demand for funding covered by domestic bank credit creation $(\triangle C>0)$. The presence of banks allows the funding of nonfinancial and financial investment not only from existing savings but also from credit (i.e., new money) created by the banks. Nominal investment can temporarily be higher than saving:

(equation 14) $P^{n f} I^{n f}+P^{f} I^{f}>S^{n}$

During the upswing nonfinancial investment grows, as low interest rates set by central banks signal higher present savings

${ }^{23}$ Money is created by banks through credit expansion. See also the loanable funds theory of Ohlin (1937). In a financially open economy, financial and nonfinancial investment can also be financed by net foreign lending. 
and thereby higher future consumption (Mises 1912; Hayek 1931). Resources are redirected from the production of consumer goods to the production of capital goods. ${ }^{24}$ Alternatively, financial investment increases. As deposit rates are low, consumers have an incentive to withdraw deposits from banks and buy stocks of enterprises and banks, whose profits increase during the upswing. If equity prices are expected to rise further, speculation may set in, with the valuation of equities becoming delinked from their fundamentals. A credit boom evolves, with prices of nonfinancial and financial investment rising. The speculative boom may also attract additional funds from abroad, as observed during the 2003-07 US subprime boom and the boom in the southern European countries during the same time period.

When rising wages force enterprises to lift prices, a central bank targeting goods price inflation is forced to increase the interest rate. At higher interest rates nonfinancial and financial investments with comparatively low expected returns become unprofitable and need to be abandoned. As the central bank keeps the interest rate high during the downswing, the commercial banks tighten credit $(\Delta C<0)$. Nonfinancial and financial investments have to be abandoned, and their prices fall. In the resulting recession, unemployment rises.

If central banks change interest rates in an asymmetric way-i.e., interest rates are cut more during the recession than they are lifted during the recovery from the crisis to prevent unemployment $t^{25}-$ interest rates will gradually decline toward zero, as shown in figure 1. The average productivity of investment will also be affected: while during the upswing financial and nonfinancial

\footnotetext{
${ }^{24}$ As this tightens the supply of consumer goods, prices of consumer goods will drift upward.

${ }^{25}$ From a historical perspective it has been argued -in line with the overinvestment theory - that the Federal Reserve kept monetary policy too tight during the Great Depression (Bernanke 1983). Under Federal Reserve chairman Alan Greenspan an asymmetric policy emerged with an eye to stock prices. Monetary policy tended to respond to falling stock prices while refraining from intervening against rising stock prices on the grounds that bubbles could not be identified (Hoffmann 2009). In the so-called Jackson Hole consensus, US central bankers agreed that central banks do not have sufficient information to spot and prick bubbles but should intervene in times of financial turmoil (Blinder and Reis 2005).
} 
investments with comparatively low marginal productivity are realized, these investment projects are not scrapped in the downswing. The average productivity of investments declines, and growth weakens.

\section{EMPIRICAL EVIDENCE}

In both the Keynesian/neoclassical and the Austrian models, the natural or neutral interest rate is a theoretical concept which cannot be observed directly in reality. Empirical estimates of the natural interest rate, as discussed earlier, are only as reliable as the underlying model is an appropriate representation of reality. Any specification errors would be captured by the interest rate derived from the model. The Keynesian model does not model the banking sector and ignores credit (or money) creation by banks. Furthermore, the Phillips curve, relating the output gap to inflation, on which the Keynesian model relies, has flattened and become unstable in most industrialized countries. ${ }^{26}$

\section{Global Savings Glut, Aging Societies, and Increasing Inequality}

A core argument of the secular stagnation hypothesis is that interest rates have been driven down by aging societies, in which people save more for retirement (section 2). This would imply that low birth rates in the industrial countries and China would go along with growing household savings rates.

To provide empirical evidence for the savings glut hypothesis, Demary and Voigtländer (2018) create an econometric model estimating real interest rate developments in twenty-four Organisation for Economic Co-operation and Development (OECD) countries with proxies for the savings glut (life expectancy, old-age dependency, young-age dependency) and secular stagnation hypotheses (total factor productivity growth, labor force growth). In contrast to the secular stagnation hypotheses, total factor productivity growth has no statistically significant effect on real interest rates in their estimates. In contrast to the savings glut hypothesis,

\footnotetext{
${ }^{26}$ See Hooper, Mishkin, and Sufi (2012); and Israel (2017).
} 
both the old- and young-age dependency ratios have a statistically significant negative influence on real interest rates. ${ }^{27}$

Empirically the link between aging populations and household savings rates is weak. The most prominent example is Japan, where since the 1980s the fast aging of the society has come along with declining household savings rates. Figure 2 shows that together with the short-term interest rate, which has been pushed down by the Bank of Japan to zero, household net savings as a percentage of GDP and as percentage of disposable income has declined as well. Latsos (2019) shows empirically that the main determinant of Japanese household savings rates has been the declining interest rate set by the Bank of Japan, with interest rate cuts constituting an incentive to save less. This is in stark contrast to the aging population hypothesis of Bernanke (2005), Summers (2014), and Weizsäcker (2014).

\section{Figure 2. Household Saving Rate and Short-Term Interest Rate in Japan}

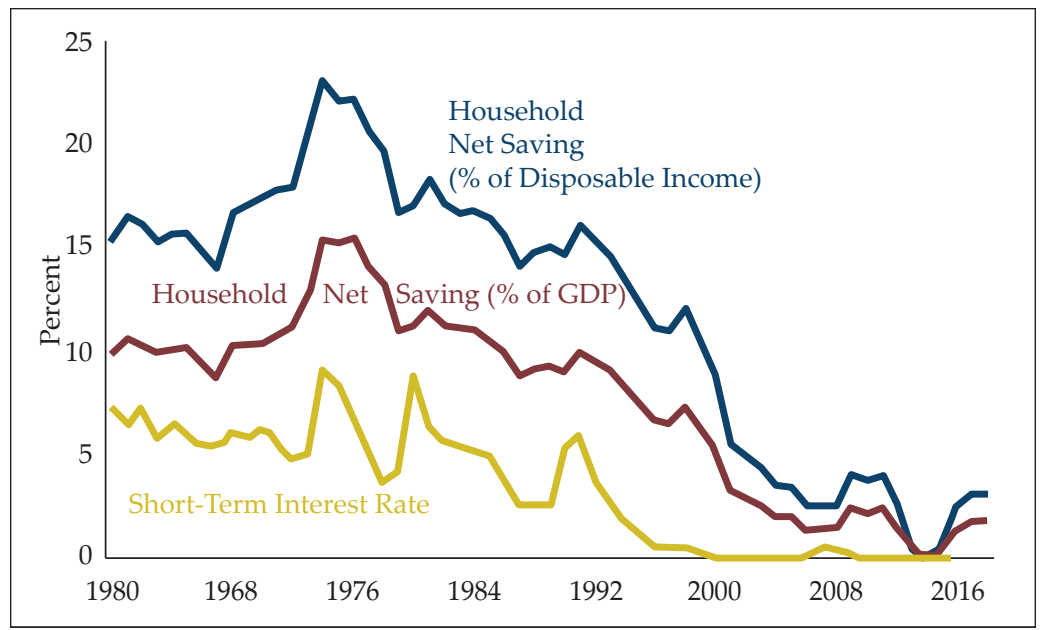

Source: OECD, IMF, Bank of Japan.

\footnotetext{
${ }^{27}$ These results are inconsistent with both the savings glut and the secular stagnation hypotheses. Furthermore, the specification ignores credit creation for investment by the banking sector and interest rate setting by central banks as determinants of the real interest rate, therefore suffering from omitted variable bias.
} 
A broader sample of OECD countries also shows no robust evidence of a correlation between aging populations and growing household savings rates. Figure 3 shows the change in the old-age dependency ratios of several OECD countries ${ }^{28}$ since 1995 on the $x$ axis, calculated by subtracting the old-age dependency ratio in 1995 from the old-age dependency ratio in 2018. A positive value indicates an aging population. The populations of all the OECD countries in the sample have aged according to this measure. Japan stands out as a particularly fast-aging country. The y axis shows the difference in the household savings rate between 2018 and 1995 in percentage points. A negative (positive) value indicates a declining (increasing) household savings rate since 1995. Based on this measure, the majority of the countries experienced a decline in the household savings rate. The aging-society-savings-glut hypothesis would imply a close positive relationship between the two indicators in form of an upward-trending line moving from left to right. But there is no correlation at all.

Instead of household savings rates, enterprise savings rates have increased in some industrialized countries such as Germany and Japan (figure 4). This has been due to three reasons. First, interest rate cuts have reduced the financing costs of enterprises, which traditionally have been borrowers in capital markets. Lower interest expenses have raised retained earnings. Second, for the enterprises of export-oriented economies, such as Japan and Germany, depreciation of the domestic currencies caused by strong monetary expansions has generated windfall profits. Third, fixed capital investment as percent of GDP has tended to decline. This could be explained, in the tradition of Hansen (1939), by slowing population growth (Summers 2014) and slowing technological innovation (Gordon 2012). More likely, however, enterprises expected lower demand owing to downward pressure on real wages because of relaxed interest rate constraints (see below).

${ }^{28}$ Countries where data were unavailable are excluded. 
Figure 3. Old-Age Dependency and Household Savings Rates in OECD Countries, 1995-2018

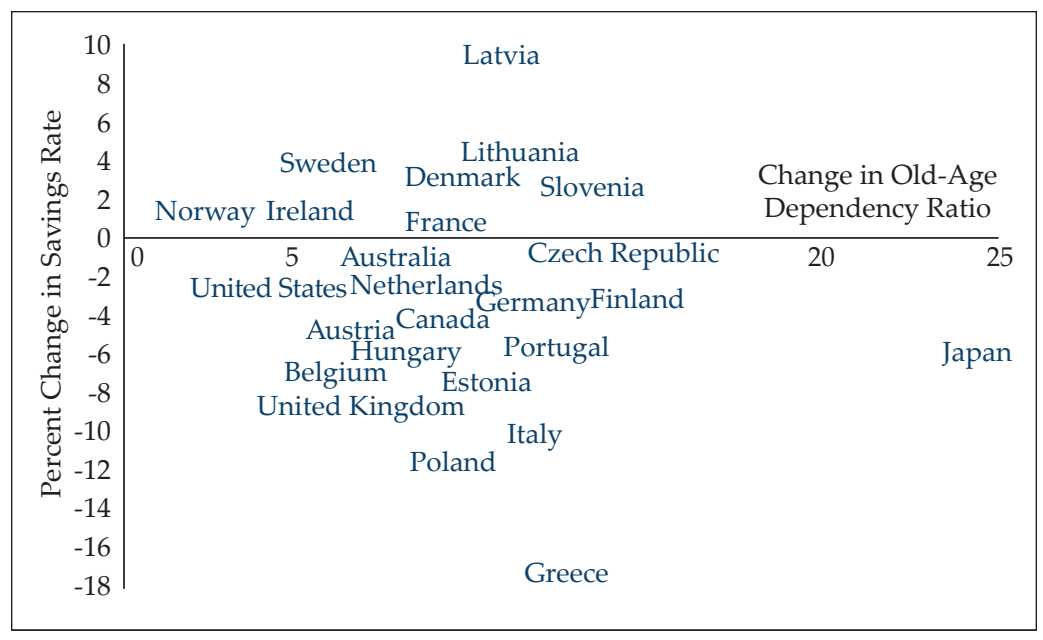

Source: OECD. Changes in household savings rates as a percent of GDP.

Finally, Summers (2014) argues that increased income inequality reduces (increases) the propensity to consume (save). However, growing income and wealth inequality may not be driven by "the laws of capitalism" (as, for instance, suggested by Piketty 2014), but by expansionary monetary policies (see Duarte and Schnabl 2018). The redistributive effects of persistently loose monetary policies have several dimensions.

One important transmission channel for growing wealth inequality is asset prices, which ultraloose monetary policies drive up, since assets are disproportionately held by wealthier people. In contrast, the interest rates on bank deposits, which are the preferred saving vehicle of the middle- and lower-income classes, are depressed in real terms into negative territory. Growing income inequality can also arise from the negative impact of persistently loose monetary policy on real wages, as will be explained below. 
Figure 4. Net Corporate Lending in the US, Japan, Germany, and China

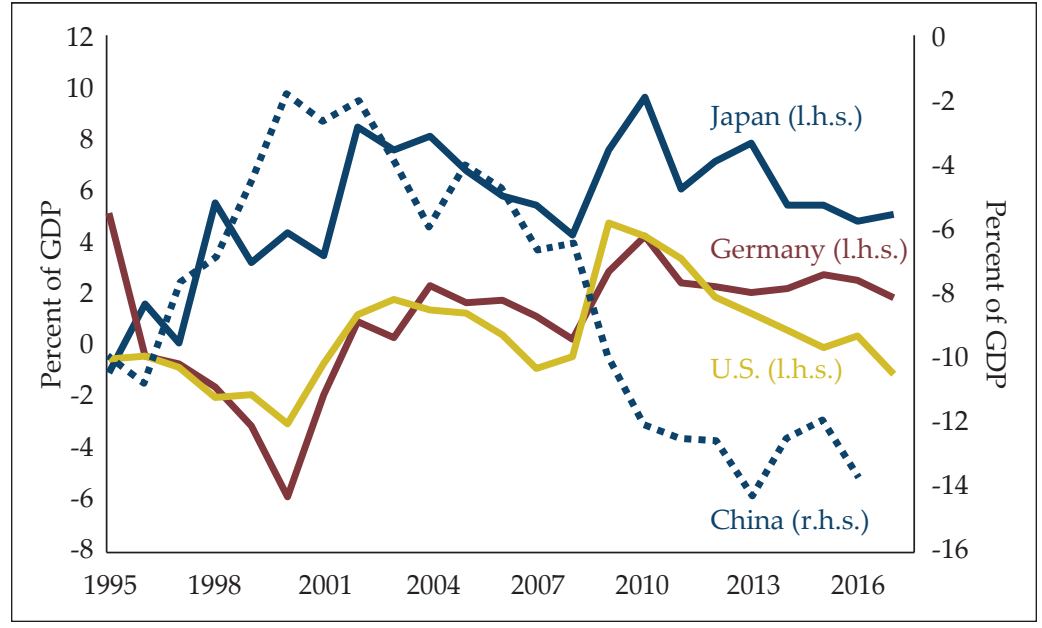

Source: OECD. Corporate net lending is equivalent to enterprises' net savings minus net investment, plus net capital transfers, minus acquisitions less disposals of nonfinancial nonproduced assets.

\section{Constant Marginal Efficiency of Investment in Industrialized Countries}

The neoclassical extension of the IS model by Gordon (2012) assumes that the marginal productivity of capital has declined, possibly into negative territory. Figure 5 shows that this hypothesis cannot be supported empirically for industrialized countries such as the US, Japan, and Germany. The marginal productivity of capital, defined according to equation (9) as the ratio of absolute change in real GDP to real investment, is largely constant in the US, Japan, and Germany. ${ }^{29}$

Apart from the cyclical downturn during the global financial crisis in 2008-09, the marginal productivity has remained positive and fairly stable around 10 percent. This implies that gradual interest rate cuts and increasing money creation by the large central banks in the industrialized countries have not boosted real nonfinancial

${ }^{29}$ The data look similar for the euro area. 
investment to an extent that would lower the marginal productivity of real capital. This is consistent with the fact, that-together with slowing output growth-fixed capital investment as a percent of GDP has tended to decline, in particular in industrial countries such as Japan and Germany (see figure 6).

\section{Figure 5. Marginal Productivity of Capital of the US, Japan, China, and Germany}

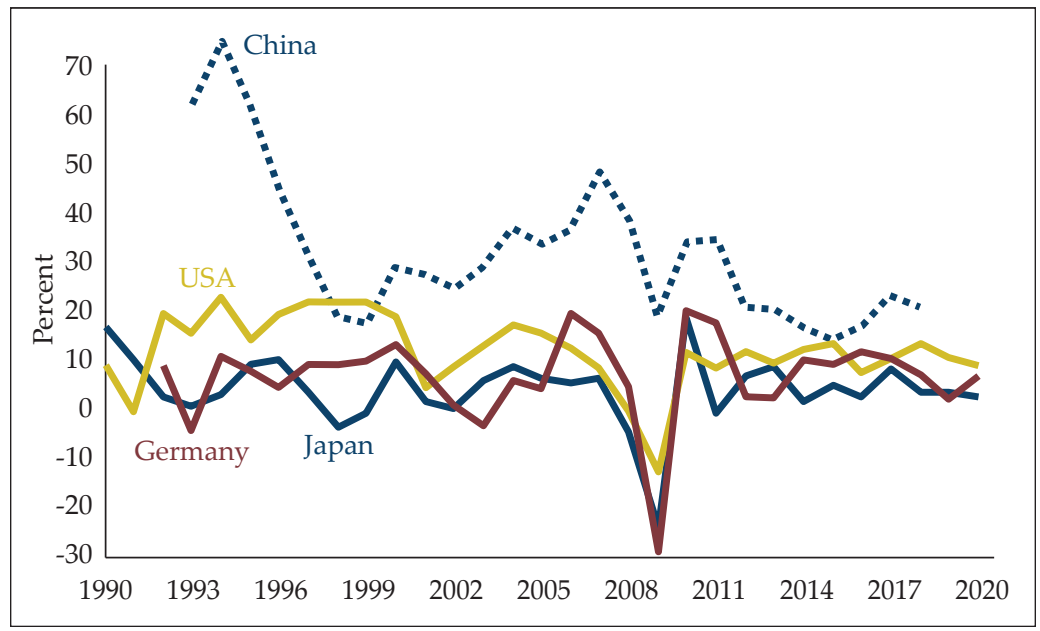

Source: AMECO. Marginal productivity of capital is defined as the absolute change in real output compared to the previous year divided by real investment of the current year.

Since the turn of the millennium-driven by capital inflows from the industrialized countries - the capital stock has expanded very fast in China (Figure 6) and other East Asian countries (Schnabl 2019b). Chinese investment (as a percent of GDP) increased far beyond that in the industrialized countries. ${ }^{30}$ At the same time, as shown in figure 5, the marginal productivity of capital in China has declined substantially since the early 1990s.

Moreover, the gradual decline of interest rates seems to have boosted real financial investment in the industrialized countries,

${ }^{30}$ Other overinvestment booms have taken place in the oil sector (shale oil), aircraft sector, and digitalization. 
with financial markets expanding. New asset classes, such as asset-backed securities, were created, and new countries, such as a number of emerging market economies, joined the international capital markets. Also, asset prices strongly increased, as shown in figure 7. Since the late 1980s, the arithmetic mean of equity and real estate prices in the US, Japan, and Germany has-with fluctuations-increased strongly relative to consumer prices. With asset prices being inflated, the marginal productivity of financial investment seems to have declined, indicated, for instance, by increasing price-to-rent ratios in many real estate markets.

\section{Figure 6. Fixed Capital Investment as a Percentage of GDP}

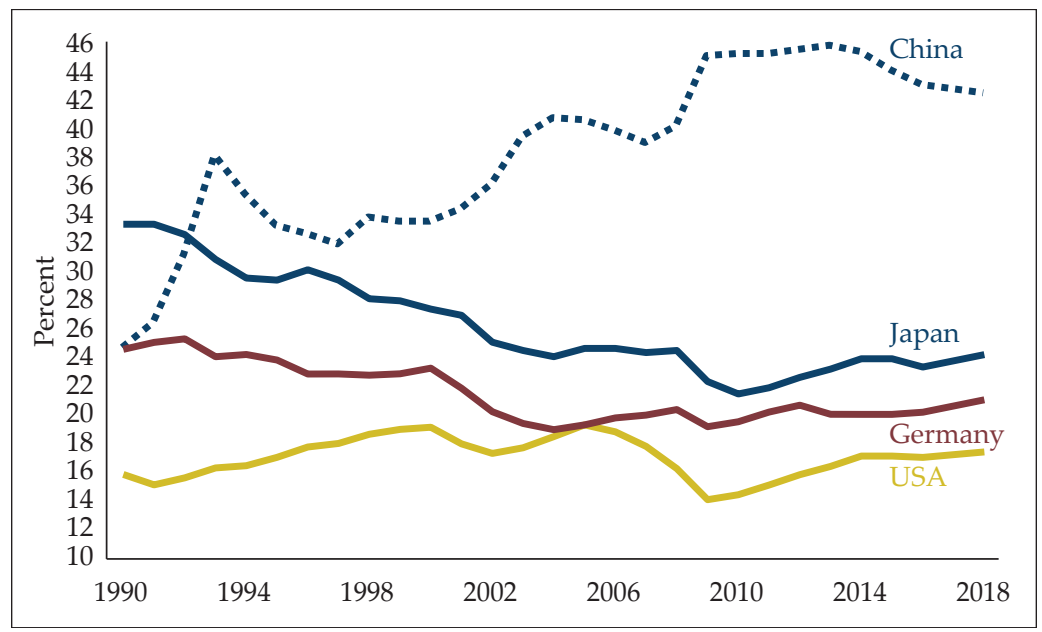

Source: IMF.

The inverse relationship between low interest rates (associated with a high degree of new money creation by central banks) and asset prices can be illustrated with the Gordon (1959) growth model of equity valuation, which relates the price-earnings ratio of enterprises to the interest rate. A simple version of this model can be written as

(15) $\frac{S P}{E}=\frac{1}{k-g}$

where $S P$ denotes the equity price per share, $E$ earnings per share, $g$ expected nominal earnings growth, and $k$ the discount rate, 
representing the financing costs of the enterprise. The secular stagnation hypothesis suggests that the price-earnings ratio of equities should have been largely unaffected by the decline in interest rates, as expected earnings growth should have declined in parallel to fading growth dynamics. Thus, the relationship between stock prices and earnings should have remained stable. On the other hand, if the interest rate decreases exogenously and expected earnings growth remains widely unchanged, the price-earnings ratio rises.

Figure 7. Consumer, Stock, and Real Estate Prices in the US, Germany, and Japan

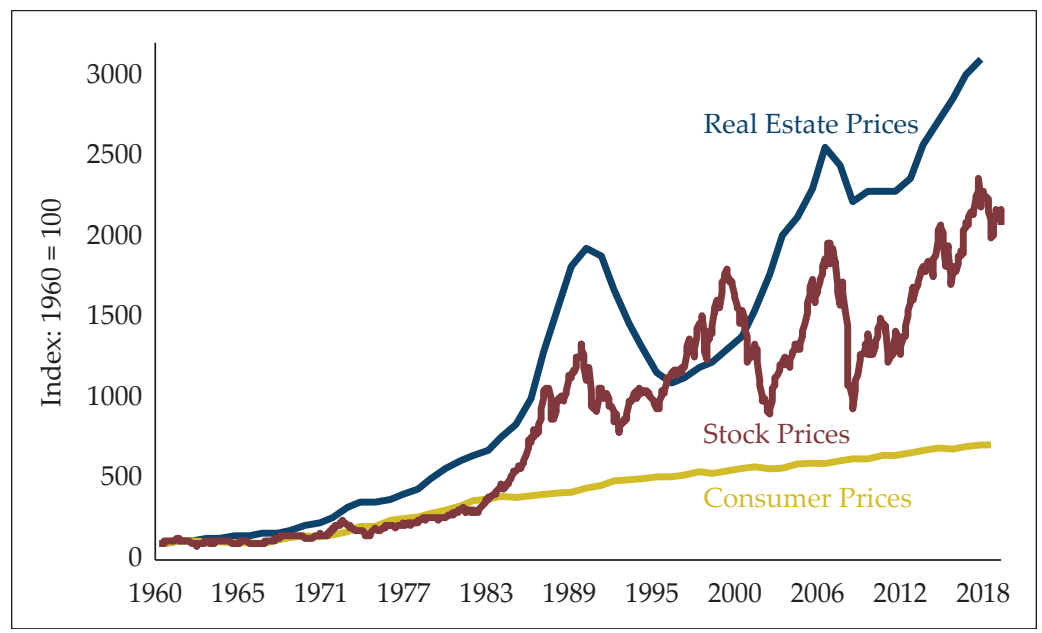

Source: IMF. Arithmetic mean.

The rise of the price-earnings ratios since the start of the global asymmetric monetary policies in the second half of the 1980s is consistent with a decline in interest rates relative to the growth of expected earnings. The US S\&P 500 Shiller cyclically adjusted priceearnings ratio has increased sharply on trend since the late 1980s (figure 8). It reached a peak in the year 2000 and has remained far above the level of the 1980s. A similarly strong expansion occurred in the second half of the 1920s before the black Friday in September 1929, which triggered the Great Depression. It seems that central 
banks pursing point inflation targets ${ }^{31}$ during a period when, inter alia, global factors have depressed inflation have not only pushed real interest rates in credit and capital markets to ever-lower levels, but have also boosted asset prices to record highs. ${ }^{32}$

\section{Figure 8. US S\&P 500 Shiller Cyclically Adjusted Price- Earnings Ratio}

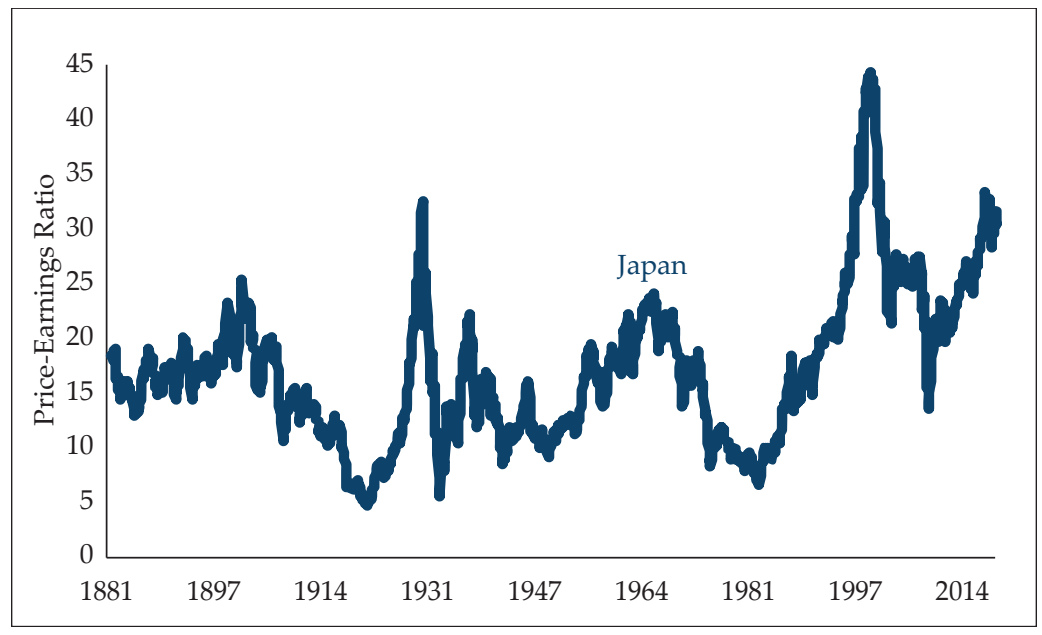

Source: Macrobond.

${ }^{31}$ As consumer price inflation rates remained very low (but above zero) following the global financial crisis, maximum inflation targets as pursued, for instance, by the ECB until 2003 would not have justified unconventional monetary policy measures. Only the shift to inflation point targets as it occurred in the case of the ECB in 2003 allowed very extensive asset purchases, which kept, for instance, the debt burden of highly indebted euro area member states sustainable (See also footnote 12). More generally, the operational rule for sound money cannot be expressed in terms of unknown natural rates.

Note that since the turn of the millennium, low interest rates in the US have boosted capital flows to China, where the capital stock has been strongly extended by borrowing abroad. Thus, large overcapacities have been created, which have led to sales at prices subsidized with cheap credit on the world markets (Schnabl 2019b). This has depressed inflation in the industrialized countries and set-given inflation point targets - the stage for further monetary expansion.

${ }^{32}$ If real wage growth slows down in an environment of slowing productivity gains, the ability of enterprises to increase prices is undermined. If, furthermore, the persistently loose monetary policies redistribute income from lower- and middle-income to highincome classes, consumer prices tend to remain low while asset prices increase. 


\section{Increasing Debt, Declining Labor Productivity, Wage and Financial Repression}

When interest rates are pushed ever lower, possibly below the growth of real income, increasing levels of debt become sustainable. It becomes more attractive for enterprises to raise their return on equity through financial leverage than through nonfinancial investment aimed at increasing productivity. ${ }^{33}$ This can be illustrated by decomposing the return to equity into profits $(R)$, equity $(E)$, turnover $(T)$, and total capital $(K) .^{34}$

$$
\text { (16) } \frac{R}{E}=\frac{R}{T} * \frac{T}{K} * \frac{K}{E}
$$

The rate of return to equity $\left(\frac{R}{E}\right)$ can be raised by increasing the profit margin $\left(\frac{R}{T}\right)$, capital productivity $\left(\frac{T}{K}\right)$, and / or financial leverage $\left(\frac{K}{E}\right)$ (through an increase of the ratio of debt to equity capital). In a competitive environment the increase in profit margins $\left(\frac{R}{T}\right)$ is limited. The productivity of capital $\left(\frac{T}{K}\right)$ has remained broadly stable over a longer time horizon, as shown in figure 11. Therefore, an increase in the return on equity $\left(\frac{R}{E}\right)$ as shown in figure 6 can be achieved only if the ratio of total capital to earnings $\left(\frac{K}{E}\right)$, i.e., the financial leverage, is increased.

\footnotetext{
${ }^{33}$ In addition, asymmetric monetary policies constitute an implicit insurance mechanism for speculation in financial markets, as interest rates are cut when asset prices collapse. The interest rate cuts either stabilize the market segments in a crisis or create alternative speculation opportunities, which allow valuation losses to be offset. In contrast, possible losses from investment in innovation and efficiency gains (i.e., fixed capital investment) have to be borne by the entrepreneurs. This policy pattern constitutes an incentive to shift resources from nonfinancial investment to financial investment. Financial investment can include takeovers of competitors and firms' buybacks of their own shares.

${ }^{34}$ The so-called Dupont analysis (see Gropelli and Ehsan 2000, 444-45).
} 


\section{Figure 9. Credit to Nonfinancial Corporations}

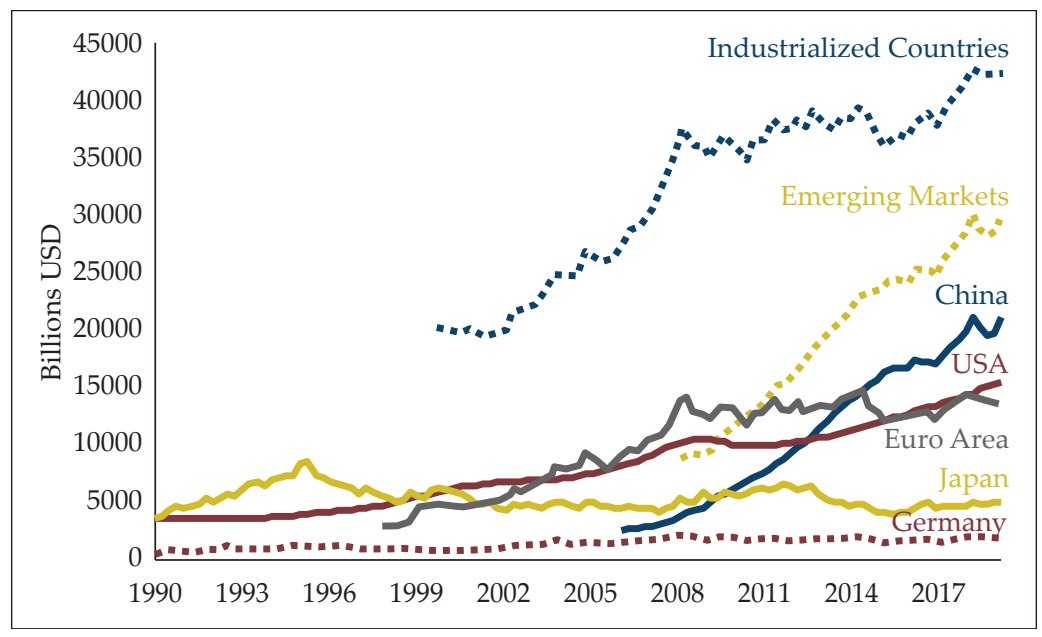

Source: BIS.

Indeed, enterprises have raised their indebtedness substantially (and much more than their output and prices), in particular in the United States and China (figure 9). In China, the additional credit has been used to build up a large real capital stock. Elsewhere it has driven financial investment more than real investment. In Germany, large enterprises in particular have strongly expanded the amount of outstanding bonds since 2008, encouraged by low interest rates and by the European Central Bank's corporate bond purchases. The additional funds have served different purposes, not the least of which have been takeovers and acquisitions. As shown in the lower panel of figure 10, the volume of mergers and acquisitions has strongly increased since the 1980s, reaching a peak in 2015. Mergers and acquisitions increased the market and pricing power, thereby creating monopolistic rents.

US enterprises have bought back large amounts of shares, which has boosted the return to equity by reducing the amount of outstanding stocks and increasing leverage. As shown in the upper panel of figure 10, stock buybacks have increased since the turn of the millennium, in particular between 2003 and 2007 as well as since 2009. The preference of large enterprises to use cheap credit for share buybacks and mergers and acquisitions instead 
of investment in new real capital can be explained by skepticism concerning future economic development. If income growth is expected to slow, extending capacities will not be effective. Instead, the price-earnings ratio can be increased by increasing leverage and profit margins, with the latter achieved by expanding market power through mergers and acquisitions. ${ }^{35}$

Figure 10. Stock Buybacks and Mergers and Acquisitions in the US

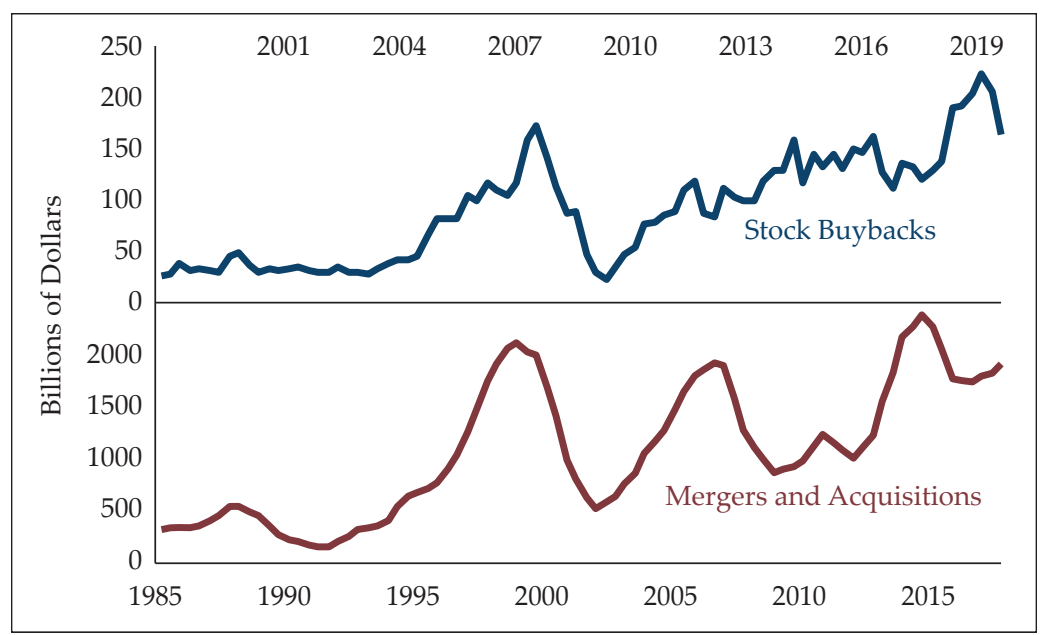

Source: Macrobond and IMMA Institute.

High equity valuations (SP/E) and low earnings yields (E/SP) should have lowered the assumed costs of equity in the evaluation of new investment projects. However, the decline in interest rates has not lowered the weighted average costs of capital, which listed companies in general use for the evaluation of new projects (Gehringer and Mayer 2017). ${ }^{36}$ Lehmann (2019) argues that listed

\footnotetext{
${ }^{35}$ Indeed, market concentration seems to have substantially increased, as found by Gutiérrez and Philippon (2017) as well as by De Loecker and Eeckhout (2017). Enterprises can charge a higher markup on prices or have stronger power versus trade unions in wage negotiations.

${ }^{36}$ The weighted cost of capital is the rate that a company is expected to pay to finance its assets. It is calculated as the weighted average of the costs of debt, i.e., the interest rate, and of internal financing, i.e., equity.
} 
companies have raised their imputed costs of equity by increasing the risk premium on equity returns as they increase leverage. ${ }^{37}$ Thus, enterprises have not followed the markets, which raised equity valuations, anticipating lower equity returns in the future.

If low interest rates induce enterprises to raise financial instead of fixed-capital investment and keep enterprises in business that would have been unprofitable otherwise, growth will decline, as overinvestment and malinvestment are conserved and capital is misallocated (Schnabl 2019a). McKinnon (1973) and Shaw (1973) showed for the developing countries and emerging market economies in the 1950s and 1960s that state-directed capital allocation at low interest rates depressed growth. ${ }^{38}$ For Japan, Schnabl (2015) shows that an ultraloose monetary policy has continued to cause financial instability and sluggish growth. ${ }^{39}$

Peek and Rosengreen (2005) argue that persistently low interest rates in Japan have constituted what they call a "perverse" incentive to keep low-return investments alive via a misallocation of credit to enterprises with low returns. Caballero, Hoshi, and Kashyap (2008) find a link between forbearing credit extensions by Japanese banks to otherwise insolvent enterprises and paralyzed market dynamics and higher costs for profitable enterprises. They also link postponed restructuring in depressed industries to lower productivity growth caused by what they call "zombie enterprises." Similarly, Acharya et al. (2019) associate low interest rates and the unconventional monetary policies of the European Central Bank with lower productivity growth in the euro area. ${ }^{40}$

\footnotetext{
${ }^{37}$ This is in line with the Modigliani-Miller theorem, which argues that abstracting from taxes, default risk, and agency costs and given perfect information, the form of financing does not affect the value of a firm (Modigliani and Miller 1958).

${ }^{38}$ McKinnon (1973) and Shaw (1973) dubbed this policy "financial repression."

${ }^{39}$ Similarly, Rungcharoenkitkul, Borio, and Disyatat (2019) argue that interest rates that are too low can induce the emergence of a new unprofitable sector in the economy, which reduces the average marginal productivity of the economy. Monetary policy that leans insufficiently against the buildup of financial imbalances increases the economy's vulnerability to financial busts over successive cycles. "As a result, low rates beget lower rates."

${ }^{40}$ See Schnabl (2019b) on overinvestment in China as well as Shen and Chen (2016) on zombie firms in China.
} 
The distorted allocation of funds comes along with distortions in the financial sector, as the ultraloose monetary policy reduces the incentive to cleanse bank balance sheets of bad loans. Furthermore, the margins of the traditional banking sector are squeezed (Gerstenberger and Schnabl 2017). With short-term interest rates being held at or below zero and long-term interest rates being pushed further down via unconventional monetary policy measures, banks' traditional sources of income-i.e., credit margins (credit rates minus deposit rates) and transformation margins (long-term interest rates minus short-term rates)—shrink. Brunnermeier and Kolby (2019) show that at some point interest rate cuts have a negative effect on credit growth, investment, and output because the positive effect of low interest rates on the valuation of bank assets is overwritten by their negative effect on bank profits. The overall value of assets falls, thereby forcing banks to restrict new lending. ${ }^{41}$

\section{Figure 11. Average Capital Productivity in the US, Japan, Germany, the Euro Area, and China}

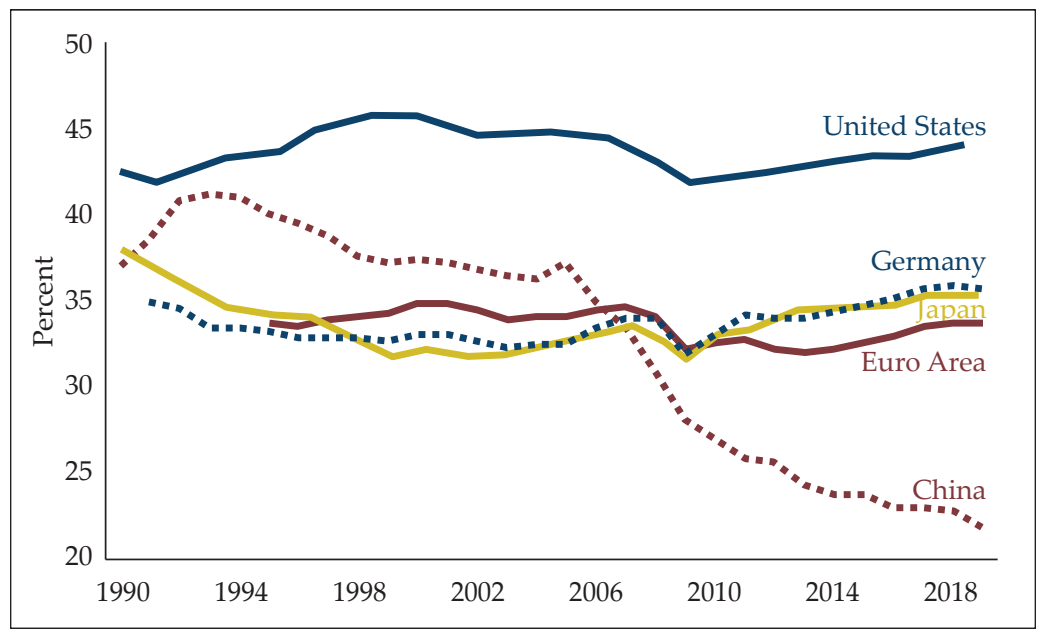

Source: AMECO Database and Penn World Tables. Average capital productivity calculated as output divided by capital stock (both in 2010/2011 prices).

${ }^{41}$ In addition, the growing regulatory burden after the financial crisis may restrict lending. 


\section{Figure 12. Real GDP and Long-Term Trend}

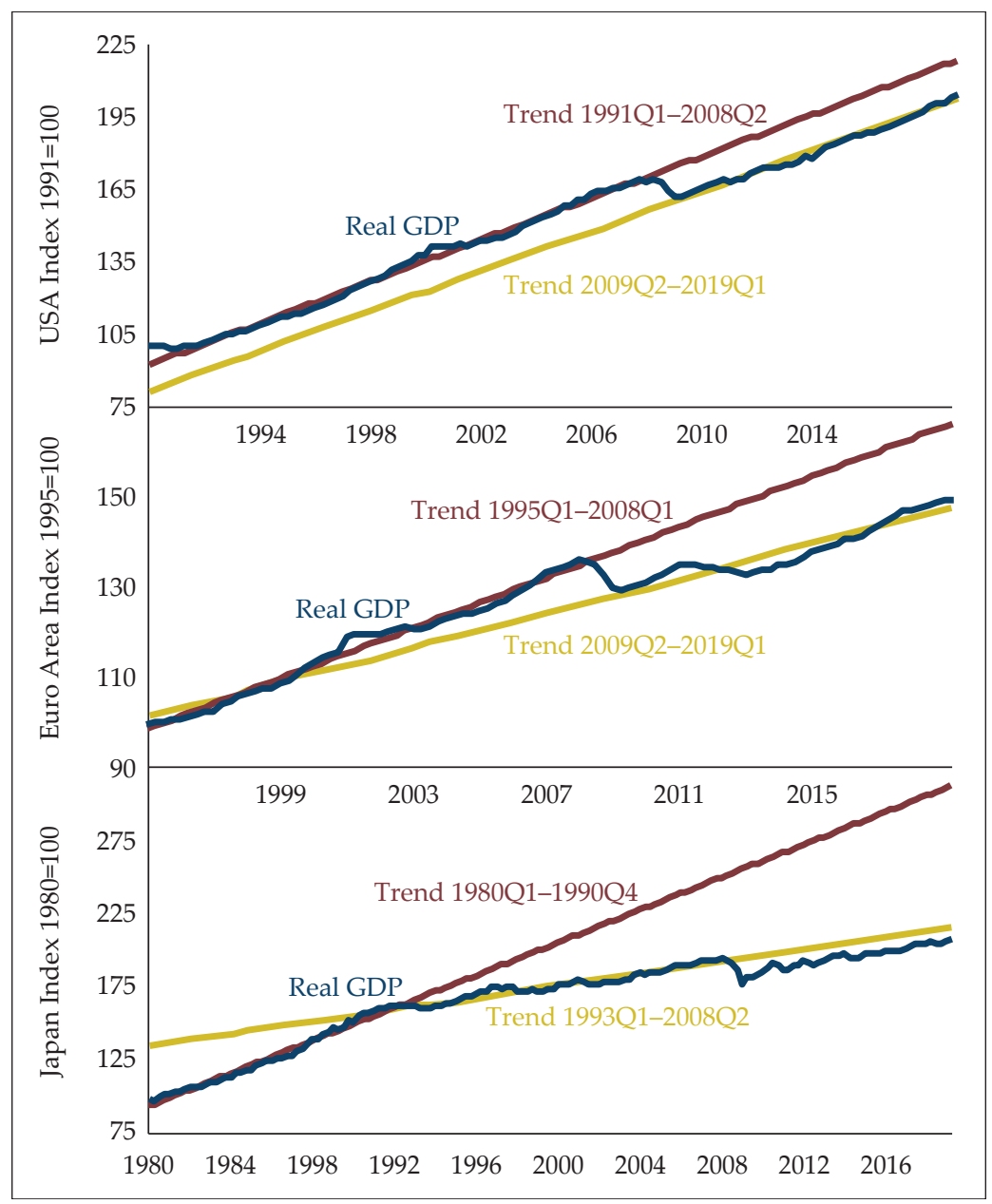

Source: Macrobond.

These findings are supported by the development of the average (in contrast to the marginal) productivity of capital over time. As shown in figure 11, average capital productivity in the US, euro area, and Japan has dropped in the wake of each financial crisis (1990-91 in Japan and 2007-08 in the US and the euro area), and it has not returned to its precrisis level in the subsequent upswing. 
The consequence has been a persistent shortfall of output below its long-term trend, as observed in Japan since the 1990s. The bursting of the so-called bubble economy triggered interest rate cuts toward zero and-after the lower zero interest rate bound was reached in 1999-comprehensive unconventional monetary policy measures, which have inflated the Bank of Japan's balance sheet from 10 percent of GDP to more than 100 percent of GDP. In contrast to the desired recovery of the Japanese economy, output has been lagging behind the long-term trend (see the bottom graph of figure 12).

Similarly, since the outbreak of the global financial crisis, the US Federal Reserve and the European Central Bank have moved to extensive unconventional monetary policy measures. As in Japan, in both the US and the euro area output has also not returned to its long-term growth path since then (see upper and center panels of figure 12). A savings glut or secular stagnation should have affected growth more gradually and should not have started with the financial crises.

The upshot is that output growth has declined while increasingly loose monetary policies have prevented or even reduced unemployment by preserving distorted economic structures. Moreover, in many countries, such as Japan and Germany, the number of employed has increased as real incomes have declined and more people have entered the labor market (Israel and Latsos 2020). Therefore, the increasingly expansionary monetary policies of the large central banks have come along with declining labor productivity gains, as shown in figure 13. 
Figure 13. Labor Productivity Gains in the US, Japan, and Germany

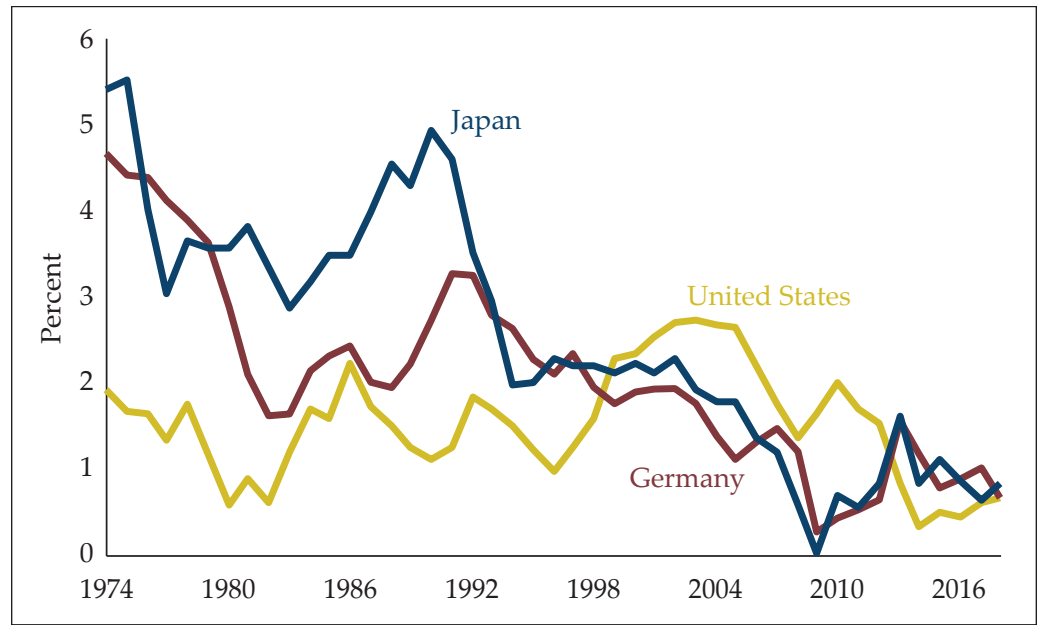

Source: OECD. Four-period backward-looking rolling averages.

In neoclassical theory, labor productivity gains are the prerequisite for real wage increases. If persistently loose monetary policies have reduced the incentives for banks and enterprises to innovate and to create productivity gains, real wage levels will be depressed. This effect is most pronounced in Japan, where real wages have been trending downward since 1998 (Latsos 2019). If enterprises expect a declining consumer purchasing power, they will hesitate to increase the capital stock, shifting their activities to financial investment. Thus, the policy of low interest rates induces the redistribution of income and wealth from wage earners to recipients of capital income and widens gender and educational pay gaps (Saiki and Frost 2014; Israel and Latsos 2020).

Kornai (1986) dubbed a similar process in the central and eastern European planned economies "soft budget constraints." Because unemployment was politically inopportune, public banks were forced to provide unconditional credit to highly inefficient enterprises. The losses of state-owned banks were covered by the printing press of the national central banks. The outcome was low or even negative productivity growth, which came along with a low consumption level compared to the western industrialized countries. From this perspective, the persistently loose monetary 
policies are quasi soft budget constraints, which have become a major impediment to productivity growth.

\section{ECONOMIC POLICY IMPLICATIONS}

The Keynesian and neoclassical schools of thought explain the secular decline of nominal and real interest rates since the 2007-08 global financial crisis as the result of a savings glut and secular stagnation. According to this view, monetary policy has only reacted to a given structural change in a new economic environment. This article has argued that both the Keynesian and neoclassical models omit the banking sector and therefore do not capture the capital market implications of asymmetric central bank interest rate cuts. The ability of banks to extend credit ex nihilo and the fact that capital goods need to be produced before they can increase the capital stock is ignored by the IS identity, which in the Keynesian theory is assumed to hold permanently. There is also no empirical evidence for the savings glut and secular stagnation hypotheses.

In contrast to the Keynesian and neoclassical models, the Austrian model incorporates the banking sector, which finances either real fixed capital or financial investment. Interest rates have become depressed by a proactive monetary policy while technological progress, closer trade ties, and overinvestment in China exerted downward pressure on prices. The global deflationary pressure originates in subsidized credit and overinvestment in China. Thus, on the back of the newly introduced point inflation targets expansionary monetary policies have boosted asset instead of goods prices and contributed to growing income inequality.

The Austrian view suggests that the depression of interest rates lowers productivity gains and trend GDP growth via quasi "soft budget constraints" for enterprises. It leads to an inefficient allocation of resources, as can be observed in Japan and increasingly in Europe. These effects have become even further magnified by the policy responses to the corona crisis. The policy implication is that only the end of the manipulation of interest rates would reanimate growth. The interest rate on credit is the most important single price in an economy. It connects a society's time preference to its ability to create capital in an efficient way. When bureaucrats at central banks 
determine the interest rate, it is a pretense of knowledge they do not have. They would truly serve society if they left the determination of interest rates to the markets.

\section{REFERENCES}

Acharya, Viral, Tim Eisert, Christian Eufinger, and Christian Hirsch. 2019. "Whatever It Takes: The Real Effects of Unconventional Monetary Policy." Review of Financial Studies 32, no. 9: 3366-3411.

Adalet McGowan, Müge, Dan Andrews, and Valentine Millot. 2017. “The Walking Dead? Zombie Firms and Productivity Performance in OECD Countries." OECD Economics Department Working Paper 1372, Paris, France, January 25.

Agarwal, Ruchir, and Miles Kimball. 2019. “Enabling Deep Negative Rates to Fight Recession: A Guide." IMF Working Paper 19/84, Washington, D.C., April 29.

Bank of Japan. 2013. "The 'Price Stability Target' under the Framework for the Conduct of Monetary Policy." News release, Jan. 22, 2013. https:// www.boj.or.jp/en/announcements/release_2013/k130122b.pdf.

Blinder, Alan, and Ricardo Reis. 2005. "Understanding the Greenspan Standard." Working paper no. 88, Center for Economic Policy Studies, Department of Economics, Princeton University, Princeton, N.J.

Bernanke, Ben S. 1983. "Nonmonetary Effects of the Financial Crisis in Propagation of the Great Depression." American Economic Review 73, no. 3: 257-76.

— . 2005. "The Global Saving Glut and the U.S. Current Account Deficit." Sandridge Lecture, Virginia Association of Economists, Richmond, Va., March 10.

—. 2014. "The Federal Reserve: Looking Back, Looking Forward." Speech given at the Annual Meeting of the American Economic Association, Philadelphia, Pa., January 3.

Böhm-Bawerk, Eugen von. 1884. Kapital und Kapitalzins. Innsbruck, Austria: Verlag der Wagner'schen Universitäts-Buchhandlung. 
Borio, Claudio, and William White. 2004. "Whither Monetary and Financial Stability? The Implications of Evolving Policy Regimes." BIS Working Papers 147, Basel, Switzerland, February.

Brunnermeier, Markus K., and Yann Koby. 2019. "The Reversal Interest Rate." IMES Discussion Paper Series 19-E-06, Bank of Japan, Tokyo, Japan, June 21.

Caballero, Ricardo, Takeo Hoshi, and Anil Kashyap. 2008. "Zombie Lending and Depressed Restructuring in Japan." American Economic Review 98, no. 5: 1943-77.

Corsetti, Giancarlo, Paolo Pesenti, and Nouriel Roubini. 1999. "Paper Tigers? A Model of the Asian Crisis." European Economic Review 43, no. 7: 1211-36.

Demary, Markus, and Michael Voigtländer. 2018. Reasons for the Declining Real Interest Rates. Cologne, Germany: Institut der deutschen Wirtschaft.

Duarte, Pablo, and Gunther Schnabl. 2018. "Monetary Policy, Income Inequality and Political Instability." World Economy 42, no. 2: 614-34.

European Central Bank. 2019. "The Relationship Between IHICP Inflation and HICP Inflation Excluding Energy and Food." ECB Economic Bulletin, Mar. 21, 2019.

Feldstein, Martin. 2017. "Underestimating the Real Growth of GDP, Personal Income, and Productivity." Journal of Economic Perspectives 31, no. 2: 145-64.

Gehringer, Agniezka, and Thomas Mayer. 2017. It's the WACC, Stupid! Cologne, Germany: Flossbach von Storch AG, Research Institute.

Gerstenberger, Juliane, and Gunther Schnabl. 2017. “The Impact of Japanese Monetary Policy Crisis Management on the Japanese Banking Sector." CESifo Working Paper Series No. 6440, Munich, Germany, April 24.

Gordon, Myron. 1959. "Dividends, Earnings, and Stock Prices." Review of Economics and Statistics 41, no. 2, pt. 1: 99-105.

Gordon, Robert J. 2012. "Is U.S. Economic Growth Over? Faltering Innovation Confronts the Six Headwinds." NBER Working Paper 18315, Cambridge, Mass., August.

Gropelli, Angelico, and Ehsan Nikbakht. 2000. Finance. 4th ed. Hauppauge, N.Y.: Barron's Educational Series. 
Gourinchas, Pierre-Olivier, and Hélène Rey. 2019. “Global Real Rates: A Secular Approach.” BIS Working Papers 793, Basel, Switzerland, July 4.

Gutiérrez, Germán, and Thomas Philippon. 2017. “Declining Competition and Investment in the U.S." NBER Working Paper 23583, Cambridge, Mass., July.

Hansen, Alvin. 1939. "Economic Stagnation and Population Growth." American Economic Review 29, no. 1: 1-15.

Hayek, Friedrich August von. 1931. Prices and Production. New York: August M. Kelly Publishers.

Hoffmann, Andreas. 2009. "Asymmetric Monetary Policy with Respect to Asset Markets." Oxonomics 4: 26-31.

Homer, Sidney, and Richard Eugene Sylla. 2005. A History of Interest Rates. 4th ed. Hoboken, N.J.: John Wiley and Sons.

Hooper, Peter, Frederic S. Mishkin, and Amir Sufi. 2019. “Prospects for Inflation in a High Pressure Economy. Is the Phillips Curve Dead or Is It Just Hibernating?" NBER Working Paper 25792, Cambridge, Mass., May.

Israel, Karl-Friedrich. 2017. "In the Long Run We Are All Unemployed?" Quarterly Review of Economics and Finance 64: 67-81.

Israel, Karl-Friedrich, and Sophia Latsos. 2020. “The Impact of (Un)Conventional Expansionary Monetary Policy on Income Inequality-Lessons from Japan." Applied Economics 52, no. 40, 4403-20.

Jordà, Òscar, and Alan M. Taylor. 2019. "Riders on the Storm." NBER Working Paper 26262, Cambridge, Mass., September.

Keynes, John Maynard. 1936. The General Theory of Employment, Interest and Money. London: Palgrave Macmillan.

Kitov, Ivan. 2012. "Why Price Inflation in Developed Countries Is Systematically Underestimated.” MPRA Paper 39059, Munich, Germany, May 27.

Komlos, John. 2018. “On the Accuracy of Estimating the Inflation Rate: Marty Feldstein as Dr. Pangloss." Economists' Voice 15, no. 1: 1-3.

Kornai, János. 1986. “The Soft Budget Constraint.” Kyklos 39, no. 1: 3-30. 
Lane, Philipp R. 2019. “Determinants of the Real Interest Rate." Speech given at the National Treasury Management Agency, Dublin, Ireland, November 28.

Latsos, Sophia. 2019. "The Low Interest Policy and the Household Saving Behavior in Japan." Working paper no. 159, Faculty of Economics and Management Science, University of Leipzig, Leipzig, Germany.

Laubach, Thomas, and John Williams. 2015. "Measuring the Natural Rate of Interest Redux." Federal Reserve Bank of San Francisco Working Paper 2015-16, San Francisco, Calif., October.

Lehmann, Kai. 2019. Wirkungslose EZB-Medizin-Kapitalkosten immun gegen Nullzins. Cologne, Germany: Flossbach von Storch AG, Research Institute.

Linz, Stefan, and Gudrun Eckert. 2002. "Zur Einführung Hedonischer Methoden in Die Preisstatistik." Wirtschaft und Statistik 10: 857-63.

McKinnon, Ronald. 1973. Money and Capital in Economic Development. Washington, D.C.: Brookings Institution Press.

McKinnon, Ronald, and Gunther Schnabl. 2012. "China and Its Dollar Exchange Rate: A Worldwide Stabilizing Influence?" World Economy 35, no. 6: 667-93.

Mises, Ludwig von. 1912. Theorie des Geldes und der Umlaufmittel. Munich, Germany: Verlag von Duncker und Humblot.

—_. (1949) 1998. Human Action: A Treatise on Economics. Scholar's ed. Auburn, Ala.: Ludwig von Mises Institute.

Modigliani, Franco, and Merton Miller. 1958. "The Cost of Capital, Corporation Finance and the Theory of Investment." American Economic Review 48, no. 3, 261-97.

Ohlin, Bertil. 1937. "Some Notes on the Stockholm Theory of Savings and Investment," Pt. 1. Economic Journal 47: 53-69.

Peek, Joe, and Eric Rosengren. 2005. “Unnatural Selection: Perverse Incentives and the Misallocation of Credit in Japan." American Economic Review 95, no. 4, 1144-66.

Piketty, Thomas. 2014. Capital in the Twenty-First Century. Cambridge, Mass.: Belknap Press of Harvard University Press. 
Rachel, Łukasz, and Lawrence H. Summers. 2019. “On Falling Neutral Real Rates, Fiscal Policy, and the Risk of Secular Stagnation." Working paper, BPEA Conference Drafts, Brookings Institution, Washington, D.C., March 4.

Rungcharoenkitkul, Phurichai, Claudio Borio, and Piti Disyatat. 2019. "Monetary Policy Hysteresis and the Financial Cycle." BIS Working Papers 817, Basel, Switzerland, October 3.

Saiki, Ayako, and Jon Frost. 2014. Does Unconventional Monetary Policy Affect Inequality? Applied Economics 46, no. 36: 4445-54.

Schnabl, Gunther. 2015a. “Die gefährliche Missachtung der Vermögenspreisinflation. Zur Wirkungslosigkeit von Inflationszielen als geldpolitische Regelmechanismen." Leviathan 43, no. 2: 246-69.

Schnabl, Gunther. 2015b. "Monetary Policy and Structural Decline: Lessons from Japan for the European Crisis." Asian Economic Papers 14, no. 1: 124-50.

Schnabl, Gunther. 2019a. "Central Banking and Crisis Management from the Perspective of Austrian Business Cycle Theory." In The Oxford Handbook of the Economics of Central Banking, edited by David G. Mayes, Pierre L. Siklos, and Jan-Egbert Sturm, 551-84. New York: Oxford University Press.

Schnabl, Gunther. 2019b. "China's Overinvestment and International Trade Conflict." CESifo Working Paper Series 7642, Munich, Germany, May.

Schnabel, Isabel. 2020. "Narratives about the ECB's Monetary PolicyReality or Fiction?" Speech given at the Juristische Studiengesellschaft, Karlsruhe, Germany, February 11.

Schumpeter, Joseph. (1912) 1934. The Theory of Economic Development: An Inquiry into Profits, Capital, Interest, and the Business Cycle. Translated by Redvers Opie. Cambridge, Mass.: Harvard University Press.

Sekine, Toshitaka, Keiichiro Kobayashi, and Yumi Saita. 2003. "Forbearance Lending: The Case of Japanese Firms." Monetary and Economic Studies 21, no. 2: 69-92.

Shaw, Edward S. 1973. Financial Deepening in Economic Development. New York: Oxford University Press.

Shen, Guangjun, and Binkai Chen. 2016. "Zombie Firms and Over-capacity in Chinese Manufacturing." China Economic Review 44: 327-42. 
Summers, Lawrence H. 2014. “U.S. Economic Prospects: Secular Stagnation, Hysteresis, and the Zero Lower Bound." Business Economics 49, no. 2: 65-73.

Taylor, John B. 1993. “Discretion versus Policy Rules in Practice.” Carnegie-Rochester Conference Series on Public Policy 39: 195-214.

Weizsäcker, Carl Christian von. 2014. "Public Debt and Price Stability." German Economic Review 15, no. 1: 42-61.

White, William R. 2006. "Is Price Stability Enough?" BIS Working Papers 205, Basel, Switzerland, April 18.

Wicksell, Knut. (1898) 2005. Geldzins und Güterpreise. Reprint, Munich, Germany: FinanzBuch Verlag.

Woodford, Michael. 2003. Interest and Prices: Foundations of a Theory of Monetary Policy. Princeton, N.J.: Princeton University Press. 